\title{
Degradation of crystal violet (CV) from aqueous solutions using ozone, peroxone, electroperoxone, and electrolysis processes: a comparison study
}

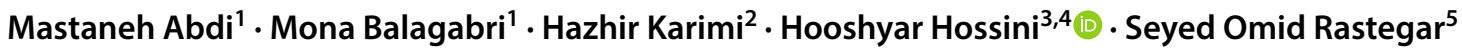

Received: 5 February 2020 / Accepted: 11 June 2020 / Published online: 23 June 2020

(c) The Author(s) 2020

\begin{abstract}
In this study, the degradation of crystal violet $(\mathrm{CV})$ was investigated by different oxidation processes; ozone (OZ), peroxone $(\mathrm{PO})$, electrolysis (E), electrolysis/ $\mathrm{H}_{2} \mathrm{O}_{2}(\mathrm{ECP})$, electroperoxone (EPO), and electrolysis/peroxene/ $\mathrm{H}_{2} \mathrm{O}_{2}(E P O P)$. Main parameters including contact time, $\mathrm{pH}, \mathrm{CV}$ concentration, and effect of scavengers were studied. The results showed that all processes were capable of $\mathrm{CV}$ decolorization. Among these processes, peroxone and electrolysis/peroxene $/ \mathrm{H}_{2} \mathrm{O}_{2}$ with efficiency about $>90 \%$ were more effective than other ones. A significant decrease in oxidation rate of CV was observed by adding scavengers. This fact was due to higher affinity to react with free radicals. To confirm degradation of CV, FTIR spectra and nitrate ion level were taken. Also, to recognize toxicity the treated wastewater was tested against coliform bacteria. Growths of Escherichia coli in EMB medium were observed. As a result, it confirms that the treated effluent can be discharged to environment.
\end{abstract}

Keywords Ozone $\cdot$ Peroxone $\cdot$ Crystal violet $\cdot$ AOPs $\cdot$ Platinum

\section{Introduction}

The triphenylmethane dyes have been extensively used for histological stain and especially Gram's Method of classifying bacteria. Also, they are used as a versatile dye in much industrial application like textile processing industries (Parshetti et al. 2011). Crystal Violet (CV), also called as gentian violet, is a species of triphenylmethane colors that is widely used for paper printing, gram staining, detergents,

Hooshyar Hossini

hoo.hosseini@gmail.com

1 Students Research Committee, Kermanshah University of Medical Sciences, Kermanshah, Iran

2 Departement of environmental science, faculty of science, University of Zakho, Kurdistan region, Iraq

3 Research Center for Environmental Determinants of Health (RCEDH), School of Public Health, Kermanshah University of Medical Sciences, Kermanshah, Iran

4 Department of Environmental Health Engineering, Faculty of Health, Kermanshah University of Medical Sciences, Kermanshah, Iran

5 Department of Chemical Engineering, University of Kurdistan, Sanandaj, Iran antiseptic (e.g., ringworm and athlete's foot), anti-freezers, fertilizers, and leather (Harifi-Mood and Hadavand-Mirzaie 2015).

Colored effluents discharging into the environment such as water resources create a major concerning its toxic effect to aquatic flora and fauna (Liu et al. 2004). Therefore, to prevent the adverse effect on biota, they should be treated before disposing to ecosystems. Various techniques including physiochemical and biological processes such as oxidation, advanced oxidation, adsorption, coagulation, membrane filtration, electrochemical processes, and ultrasonic irradiation have been suggested for degradation of synthetic dyes (Chou et al. 1999). Generally, biological processes are less effective on dyes because of inherent characteristics of dyes such as toxicity, high weight, and strong molecular bonds (azo bonds) (Lee et al. 2006). Recently, advanced oxidation processes (AOPs) have been considered as an effective and strong process for wastewater treatment because of the involved oxidative radicals (Comninellis et al. 2008). Ozone and its combination with other oxidation have been recommended for dye and organic material degradation. Under higher $\mathrm{pH}$, ozone is decomposed into hydroxyl radicals leading to the destruction of dyes molecules. However, for enough 
degradation, the ozonation $(\mathrm{OZ})$ needs more time. To give better results, the ozone is integrated with another oxidation agent (De Witte et al. 2009). One combination method applied for this purpose is a peroxone (PO) process, which uses ozone and peroxide hydrogen. This combination has a strong synergistic effect on pollutants and organic matters that mainly occur due to the generation of hydroxyl radicals (Bakheet et al. 2013). To emphases on the advantage of combination, (Al-Qodah et al. 2018) revealed that the combination of electrochemical with another process enhances the removal efficiency of water pollutants. They provided a good literatures review on increasing better pollutant removal efficiency when ozone-assisted electrocoagulation is used. This process can be integrated with electrolysis by which consumption of hydrogen peroxide can be decreased or even omitted. Referring to the literature, electroperoxone (EPO) significantly has shown the ability to degrade and mineralize organic matter and high weight molecules such as synesthetic dyes. The integration of EC with a free radical producing process has been noted as a new promising and strong procedure (Al-Qodah and Al-Shannag 2019).

Generally, in electrochemical-based process, electrode material, size, and their arrangement are the important parameters affecting the progress of reaction (Adhoum and Monser 2004). Same authors reported that the effectiveness of EC for organic degradation depends on the nature of the anodes and there is a poor current efficiency for traditional electrodes, such as graphite and nickel (Rodgers and Bunce 2001, Feng and Li 2003, Chen 2004). Li et al. demonstrated that the same electrode materials such as $\mathrm{Ti} / \mathrm{SnO}_{2}-\mathrm{Sb}, \mathrm{Ti} / \mathrm{RuO}_{2}$, and $\mathrm{Pt}$ could be used for the degradation of organic compounds such as phenol ( $\mathrm{Li}$ et al. 2005). Also, the cathode material is considered by many parameters including lower costs, stability in acidic and alkaline mediums, and low interior resistance for an electrical crossing charge. Chou and et al. have shown that the highest initial current efficiency is provided using steel cathode in contrast with graphite, titanium, and lead. Moreover, using this cathode, greater ferrous ions are produced and subsequently higher degradation rate of organic compounds occurs (Chou et al. 1999).

Platinum and platinum group metals have wide applications because of their unique properties such as stability, high resistance, melting points, and electrical conductivity. Moreover, this group is considered as rare metals and priceless material on the world. Hence, they can be permanently used after application.

The aim of this study is a comparative study to investigate the decolorization of CV based on different AOPs methods including ozone $(\mathrm{OZ})$, peroxone $(\mathrm{PO})$, electrolysis $(\mathrm{E})$, electrolysis/ $\mathrm{H}_{2} \mathrm{O}(\mathrm{EP})$, electroperoxone (EPO), and electrolysis/ peroxone $/ \mathrm{H}_{2} \mathrm{O}_{2}$ (EPOP).

\section{Materials and methods}

\section{Standards and reagents}

Crystal violet (CAS number: 548-62-9) with empirical formula $\mathrm{C}_{2} 5 \mathrm{H}_{30} \mathrm{C}_{1} \mathrm{~N}_{3}$ was prepared from Sigma-Aldrich company (Germany). Other reagents such as methanol $(\geq 99.9 \%)$, sodium acetate, EDTA, sodium bicarbonate, $\mathrm{NaCl}, \mathrm{NaOH}, \mathrm{HCl}, \mathrm{H}_{2} \mathrm{O}_{2}(35 \%)$ were provided in analytical grade and Merck Group Company (Germany). The chemicals were utilized without further purification.

\section{Experimental setup}

The oxidation experiments were carried out in a batch covered cylindrical reactor (Pyrex) with a height of $15 \mathrm{~cm}$ and an inner diameter of $10 \mathrm{~cm}$. Ozone was prepared in dry air (Aqua) by an in situ ozone generator with continuously bubbling and a constant dose ( $2 \mathrm{mg} / \mathrm{L}$.min).

To initiate the electrolysis-based oxidation, a DC power supply (TEK-8051, $30 \mathrm{~V}$, and 5 A double) was used and a constant current of $100 \mathrm{~mA}$ was applied. A pair of electrodes, a platinum rod (height of $18 \mathrm{~cm}$ and diameter of $2 \mathrm{~mm}$ ) was used as the anode and stainless steel wool was installed as the cathode with a distance of $2.5 \mathrm{~cm}$ from the reactor. The steel wool was fixed on a cylindrical plastic mesh, and platinum was placed. To better mix the reactor contents, a magnet starrier (Alfa, HS-860) was used.

In order to remove the exhausted ozone, an activated carbon Plexi column (with a height of $40 \mathrm{~cm}$ and an inner diameter of $6 \mathrm{~cm}$ ) was designed. To improve the electrical conductivity of the colored solution, $100 \mathrm{mg} / \mathrm{L}$ of sodium chloride was added directly as supporting electrolytes.

All experiments were carried out at room temperature (i.e., $22 \pm 3{ }^{\circ} \mathrm{C}$ ). The $\mathrm{pH}$ of colored solution was determined using a $\mathrm{pH}$ meter (i.e., HATCH), and the desirable $\mathrm{pH}$ was adjusted by a $1 \mathrm{M} \mathrm{NaOH}$ and $1 \mathrm{M} \mathrm{HCl}$ solutions. Finally, to determine the scavenging influences, $100 \mathrm{mg} \mathrm{w} / \mathrm{v}$ of methanol, sodium acetate, EDTA, and sodium bicarbonate were used under optimal conditions.

\section{Analysis}

During decolorization by the OZ, PO, EPO and EPOP processes, samples were collected from the reactor at different reaction times of 5, 10, 15, 20, 25, 30, 45, and $60 \mathrm{~min}$. Then, to avoid the analysis errors from sampling until the determination of $\mathrm{CV}$ residuals, $1 \mathrm{~mL}$ methanol was interred. This was done due to scavenging the existing free radical in sampled volume and further oxidation. The $\mathrm{CV}$ residual concentrations in the solution were measured spectroscopy 
through UV-visible spectrophotometer (Rayleigh UV 9200, China) at $600 \mathrm{~nm}$. The removal efficiency percentage rate was calculated using the following equation. Also, the apparent decolorization rate was determined based on general first-order kinetics.

$C V \%=\left[\frac{C V_{0}-C V_{T}}{C V_{0}}\right] \times 100$

To understand the degradation of CV, FTIR spectra were taken using infrared spectrophotometer (Tensor 27, Bruker, Germany). To prepare the samples, a volume of about $500 \mathrm{ml}$ was dried for each run and a dried powder was analyzed.

\section{Toxicity test}

To ensure the reliability of the results, detoxification test of treated wastewater was considered. The experiment was performed by adding the Coliform group bacteria to $0.5 \mathrm{ml}$ of treated wastewater. Then, the bacteria were cultured on EMB agar medium and incubated for $24 \mathrm{~h}$ at $35^{\circ} \mathrm{C}$. The Coliform bacteria were harvested from a previously prepared positive EC brace medium. Next, certain amounts of positive sample were transferred to EMB medium. Finally, the growth ability considered as a reduction of CV toxicity. Also, the toxicity of untreated was investigated as blank.

\section{Result and discussion}

\section{Time determination}

Figure 1 presents the effect of $\mathrm{OZ}$ and $\mathrm{PO}$ on $\mathrm{CV}$ removal efficiency. As can be seen, the PO is so faster and effective than $\mathrm{OZ}$ alone. Decolorization of $\mathrm{CV}$ using $\mathrm{OZ}$ was limited in the first $20 \mathrm{~min}$, and then, the $\mathrm{CV}$ concentration was declined exponentially. Additionally, about $40 \%$ of the $\mathrm{CV}$ was decolorized after $30 \mathrm{~min}$ of ozone treatment, while about $80 \%$ of the CV was reduced at this time using the PO. In comparison, Wijannarong et al. (2013) reported that only $\mathrm{OZ}$ is not able to completely remove reactive dyes such that just about $90 \%$ of primary concentration was decolorized at $6 \mathrm{~h}$ (Wijannarong et al. 2013). These results possibly occurred due to the delay in ozone decomposition in aqueous solution and consequently postponing the chain mechanism, which is combined with initiation, propagation, and termination (Wijannarong et al. 2013). Simple ozone decomposition and model decomposition were described by (Hoigné et al. 1985, Wijannarong et al. 2013).

Ozone is stable at lower pH (Acar and Ozbelge 2006) and thus inhibits ozone decomposition with regard to unadjusted initial $\mathrm{pH}(6.8 \pm 0.1)$ of $\mathrm{CV}$ solution. Also, the presence of
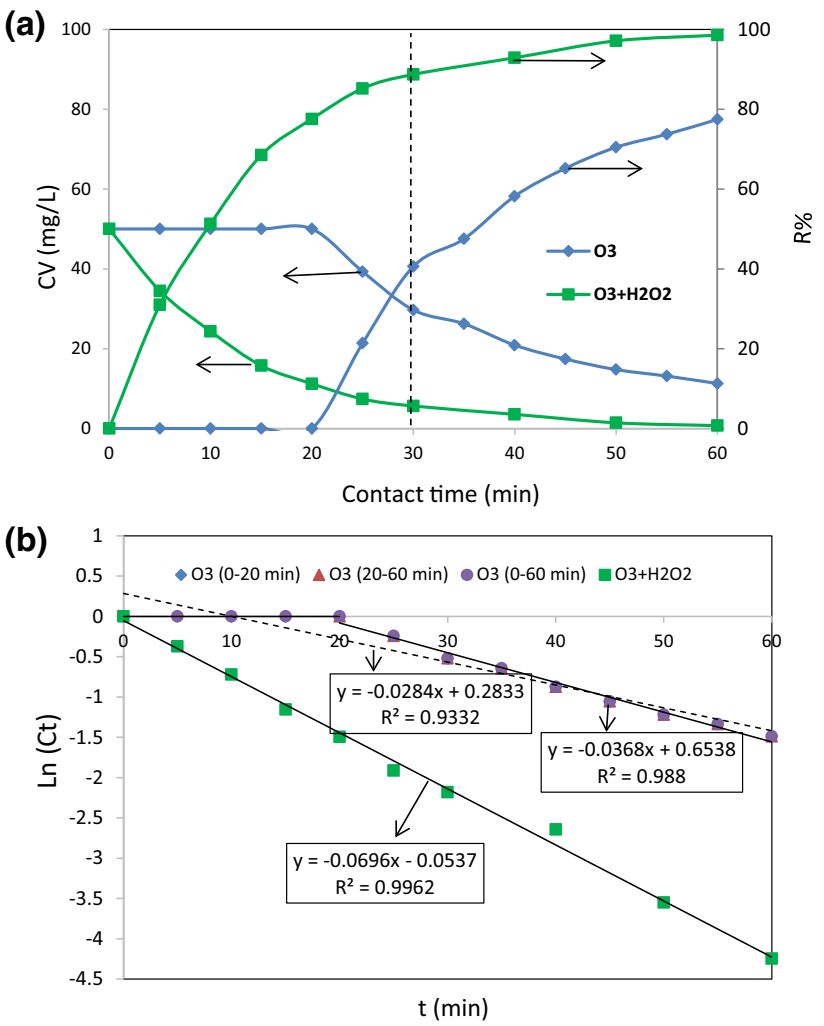

Fig. 1 Effect of OZ and PO on CV decolorization a first-order kinetic evaluation b [condition: reactor volume $500 \mathrm{cc}$ and $70 \mathrm{rpm}$, unadjusted $\mathrm{pH}$, initial $\mathrm{CV}$ concentration $50 \mathrm{mg} / \mathrm{L}$, ozone $2 \mathrm{mg} / \mathrm{L}$. min, and $\left.\mathrm{H}_{2} \mathrm{O}_{2} 15 \mathrm{mmol} / \mathrm{L}\right]$

some ions like $\mathrm{OH}^{-}$can enhance the decomposition of ozone by launching the chain mechanism. Therefore, the acidic medium can make a lag phase during $\mathrm{OZ}$ process. Furthermore, in the presence of $\mathrm{OH}^{-}$, the ozone decomposition is started as Eq. (2), which takes place very slowly by a constant rate of $70 \mathrm{M}^{-1} \mathrm{~s}^{-1}$ (Wijannarong et al. 2013).

$\mathrm{O}_{3}+\mathrm{HO}^{-} \rightarrow \mathrm{HO}_{2}^{-}+\mathrm{O}_{2}^{-\cdot} \quad k=70 \mathrm{M}^{-1} \mathrm{~s}^{-1}$

As previously mentioned, the ozone decomposition is enhanced in the presence of other oxidant agents such as UV, catalyst, or hydrogen peroxide. In the case of hydrogen peroxide, which is used with ozone, the chain reactions initialize. Launching by $\mathrm{HO}_{2}^{-}$, which is arising from partial ionization of hydrogen peroxide, can be described as the following equations (Acar and Ozbelge 2006, Al-Qodah and Al-Shannag 2019):

$\mathrm{O}_{3}+\mathrm{HO}_{2}^{-} \rightarrow \mathrm{HO}_{2}^{-}+\mathrm{O}_{2}^{-\cdot} \quad k=2.8 \times 10^{6} \mathrm{M}^{-1} \mathrm{~s}^{-1}$

$\mathrm{O}_{3}+\mathrm{O}_{2}^{-\bullet} \rightarrow \mathrm{O}_{3}^{-\cdot}+\mathrm{O}_{2} \quad k=1.6 \times 10^{9} \mathrm{M}^{-1} \mathrm{~s}^{-1}$ 
$\mathrm{H}^{+}+\mathrm{O}_{3}^{-\cdot} \rightarrow \mathrm{HO}_{3}^{\cdot} \quad k=5.2 \times 10^{10} \mathrm{M}^{-1} \mathrm{~s}^{-1}$

$\mathrm{HO}_{3}^{\cdot} \rightarrow \mathrm{HO}^{\bullet}+\mathrm{O}_{2} \quad k=1.1 \times 10^{5} \mathrm{M}^{-1} \mathrm{~s}^{-1}$

$\mathrm{HO}^{\bullet}+\mathrm{O}_{3} \rightarrow \mathrm{HO}_{4}^{\cdot} \quad k=2.0 \times 10^{9} \mathrm{M}^{-1} \mathrm{~s}^{-1}$

$\mathrm{HO}_{4}^{\cdot} \rightarrow \mathrm{HO}_{2}^{\cdot}+\mathrm{O}_{2} \quad k=2.8 \times 10^{4} \mathrm{M}^{-1} \mathrm{~s}^{-1}$

$2 \mathrm{HO}_{4}^{\cdot} \rightarrow \mathrm{H}_{2} \mathrm{O}_{2}+2 \mathrm{O}_{3} \quad k=5.0 \times 10^{9} \mathrm{M}^{-1} \mathrm{~s}^{-1}$

$\mathrm{HO}_{4}^{-}+\mathrm{HO}_{3}^{\cdot} \rightarrow \mathrm{H}_{2} \mathrm{O}_{2}+\mathrm{O}_{3}+\mathrm{O}_{2} \quad k=5.0 \times 10^{9} \mathrm{M}^{-1} \mathrm{~s}^{-1}$

Because of the higher reaction rate of $\mathrm{HO}_{2}^{-}\left(k=2.8 \times 10^{6} \mathrm{M}^{-1} \mathrm{~s}^{-1}\right)$ than $\mathrm{OH}^{-}, \mathrm{PO}$ is more efficient than ozone. The first reaction rate of $\mathrm{PO}$ is 40,000 times faster than $\mathrm{OZ}$ alone.

To determine the overall decolorization rate of $\mathrm{OZ}$ and $\mathrm{PO}$, the first-order kinetic was considered (Rezaee et al. 2016):

$\operatorname{Ln}\left(\frac{C_{t}}{C_{0}}\right)=-k t$

where $\mathrm{C}_{0}$ and $\mathrm{C}_{\mathrm{t}}$ are the $\mathrm{CV}$ concentrations at the beginning of the decolorization process and after time $t$, respectively. Also, $k_{1}$ is the constant of first-order kinetics. Figure $1 b$ presents the values of $k_{1}\left(\mathrm{~min}^{-1}\right)$ and its correlation coefficients $\left(R^{2}\right)$. To better understand the reaction rate, the $\mathrm{k}_{1}$ was determined separately for the delay phase of OZ oxidation (0-20 min) and active period time $20-60 \mathrm{~min}$. It is obvious that the delay phase did not have any progress (according to zero slopes). But, later, the rate of $\mathrm{OZ}$ oxidation reached $0.0368 \mathrm{~min}^{-1}$. In comparison, the PO was faster and stronger than $\mathrm{OZ}$ by a higher amount of $\mathrm{k}_{1}$, i.e., $0.0696 \mathrm{~min}^{-1}$. Also, higher kinetic correlation coefficients (i.e., $R_{\mathrm{OZ}}^{2}=0.933$ and $R_{\mathrm{OP}}^{2}=0.996$ ) indicated good conformity between first-order kinetics and oxidation data. Additionally, according to the $\mathrm{k}_{1, \mathrm{OP}}$ and $\mathrm{k}_{1, \mathrm{oz}}$ (for time 0-60 min), it is clear that the peroxene oxidation rate is 2.45 time greater than $\mathrm{OZ}$ alone.

At the time of $60 \mathrm{~min}$, the decolorization efficiency was about less than $80 \%$ and more than $98 \%$ for OZ and PO processes, respectively. Since the greatest removal rate of CV was achieved about $30 \mathrm{~min}$, the end of other experiments was set at $30 \mathrm{~min}$.

\section{Comparison different combination: EC, EP, EPO, EPOP}

The oxidation ability of electrolysis and its combination with ozone and hydrogen peroxide were investigated. As shown in Fig. 2, there is the potential oxidation of the electrochemical process and its different arrangements with ozone and $\mathrm{H}_{2} \mathrm{O}_{2}$. It is obvious that the combination arrangements provided better results. The combinations of electrolysis with ozone and $\mathrm{H}_{2} \mathrm{O}_{2}$ including $\mathrm{EP}$, EPO (electrolysis $/ \mathrm{O}_{3}$ or electroperoxone), and EPOP were more effective. The residual amounts of $\mathrm{CV}$ at the end of the process for electrochemical, EP, EPO, and EPOP were determined about $45.5 \mathrm{mg} / \mathrm{L}$, $14.6 \mathrm{mg} / \mathrm{L}, 19.33 \mathrm{mg} / \mathrm{L}$, and $7.36 \mathrm{mg} / \mathrm{L}$, respectively. This result showed that higher decolorization efficiency is provided when using EPO (70\%) and EPOP (85.3\%).

At an equilibrium relationship, $\mathrm{H}_{2} \mathrm{O}_{2}$ dissociation to hydroperoxide ions $\left(\mathrm{HO}_{2}^{-}\right)$can be described as Eq. (12) (Acar and Ozbelge 2006). However, in the presence of a sufficient amount of $\mathrm{H}_{2} \mathrm{O}_{2}$, the equilibrium produces more $\mathrm{HO}_{2}{ }^{-}$. Since the needed hydrogen peroxide for EPO process is generated from electrolysis, its generation rate is limited. As a result, the better degradation of $\mathrm{CV}$ was observed when adding hydrogen peroxide externally.

$\mathrm{H}_{2} \mathrm{O}_{2} \leftrightarrow \mathrm{HO}_{2}^{-}+\mathrm{H}^{+}$

Moreover, to achieve an efficient decolorization, the appropriate ratio of $\mathrm{H}_{2} \mathrm{O}_{2}$ to ozone should be available.
Fig. 2 Effect of electrolysis and its combinations with ozonation and peroxone on CV decolorization [condition: reactor volume $500 \mathrm{cc}$ and $70 \mathrm{rpm}$, applied current $0.1 \mathrm{~A}, \mathrm{NaCl}$ $100 \mathrm{mg} / \mathrm{L}$, unadjusted $\mathrm{pH}$, initial CV concentration $50 \mathrm{mg} / \mathrm{L}$, ozone $2 \mathrm{mg} / \mathrm{L}$. $\min$ and $\mathrm{H}_{2} \mathrm{O}_{2}$ $15 \mathrm{mmol} / \mathrm{L}]$
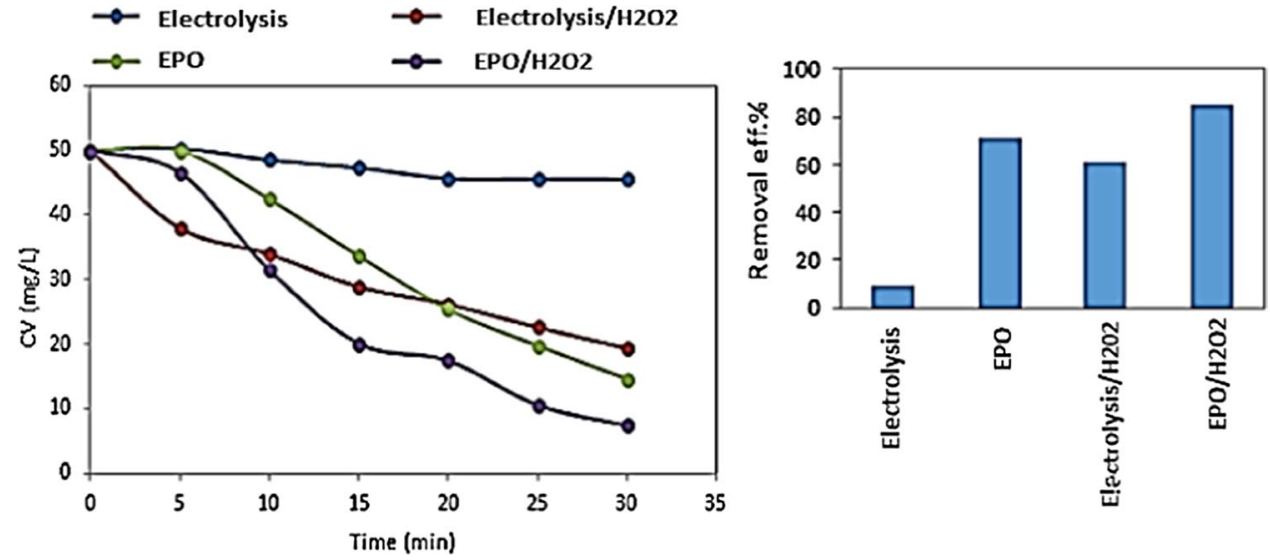
However, productive or external $\mathrm{H}_{2} \mathrm{O}_{2}$ can be as main limiting agent for $\mathrm{PO}$ and peroxone-based reactions. Also, it is of note that the excessive amount of hydrogen peroxide acts as a scavenger and consequently the efficacy of process due to self-consumption of free oxidative radical is diminished (Glaze 1987). Although among the electroperoxone processes the highest efficiency was related to EPOP, the classic PO showed better performance. This fact can result from the adequate and adjustable ratio of $\mathrm{H}_{2} \mathrm{O}_{2}$ to $\mathrm{O}_{3}$ and also the absence of electrolysis products such as oxygen or undesirable released anodic materials.

\section{The effect of different parameters}

\section{Effect of $\mathrm{pH}$}

The $\mathrm{pH}$ is one of the main controlling parameters of the chemical and biochemical treatment processes such as advanced oxidation and biological processes. Figure $3 \mathrm{a}$ and $\mathrm{b}$ shows the effect of initial $\mathrm{pH}$ and its role in $\mathrm{PO}$ and EPOP processes.

As shown in Fig. 3a, it is evident a higher $\mathrm{pH}$ ( $\mathrm{pH} 7$ and 9 ) is more effective on the oxidation processes and more than $98 \%$ of removal efficiency was obtained at time of 5 min. Also, it can be seen that at pH 5 the PO has the lowest efficiency with about 50\% removal efficiency.

According to Fig. 3b, the maximum dye degradation was $82.7 \%$ when the $\mathrm{pH}$ was adjusted at 9 . Because the $\mathrm{CV}$ has two acid dissociation constants (i.e., $\mathrm{pKa}_{1} 5.31$ and $\mathrm{pKa}_{2}$ 8.64), it is expected that the decolorization of $\mathrm{CV}$ at higher than these amounts is more effective. Therefore, higher removal of $\mathrm{CV}$ at basic $\mathrm{pH}$ matches with dissociation constants. Also, the cationic structure of the $\mathrm{CV}$ favors decolorization at higher $\mathrm{pH}$ values (Sihem et al. 2008). Acar and Ozbelge (2006) reported determined the maximum and lowest ozone concentrations at $\mathrm{pH} 2.5$ and $\mathrm{pH} 10$, respectively (Acar and Ozbelge 2006). Also, they found that a faster decomposition rate of ozone is related to basic $\mathrm{pH}$ in an aqueous medium. These results demonstrate that the basic $\mathrm{pH}$ can prompt the $\mathrm{PO}$-based oxidation processes. Zhang et al. (2010) showed that with an increase in the $\mathrm{pH}$ value, the rate of $\mathrm{H} 2 \mathrm{O} 2$ decomposition increased and, as a result, more free radicals would be generated. This fact can be described through Eqs. 13 and 14:

$\mathrm{H}_{2} \mathrm{O}_{2}+\mathrm{e} \leftrightarrow{ }^{\bullet} \mathrm{OH}+\mathrm{OH}^{-}$

$\mathrm{H}_{2} \mathrm{O}_{2} \leftrightarrow \mathrm{HO}_{2}^{-}+\mathrm{H}^{+}+\bar{e}$

Also, it can be noted that at low $\mathrm{pH}$ levels, protons can be scavenged by the hydroxyl radical as Eq. (15), leading to a decrease in $\mathrm{CV}$ decolorization rate.

$\cdot \mathrm{OH}+\mathrm{H}^{+}+\bar{e} \leftrightarrow \mathrm{H}_{2} \mathrm{O}$
Fig. 3 Effect of $\mathrm{pH}$ on peroxone a and e-peroxone/H2O2 (b) efficiency [condition: reactor volume $500 \mathrm{cc}$ and $70 \mathrm{rpm}$, applied current $0.1 \mathrm{~A}, \mathrm{NaCl}$ $100 \mathrm{mg} / \mathrm{L}$, initial CV concentration $50 \mathrm{mg} / \mathrm{L}$, ozone $2 \mathrm{mg} / \mathrm{L}$. min and $\mathrm{H}_{2} \mathrm{O}_{2} 15 \mathrm{mmol} / \mathrm{L}$ ]
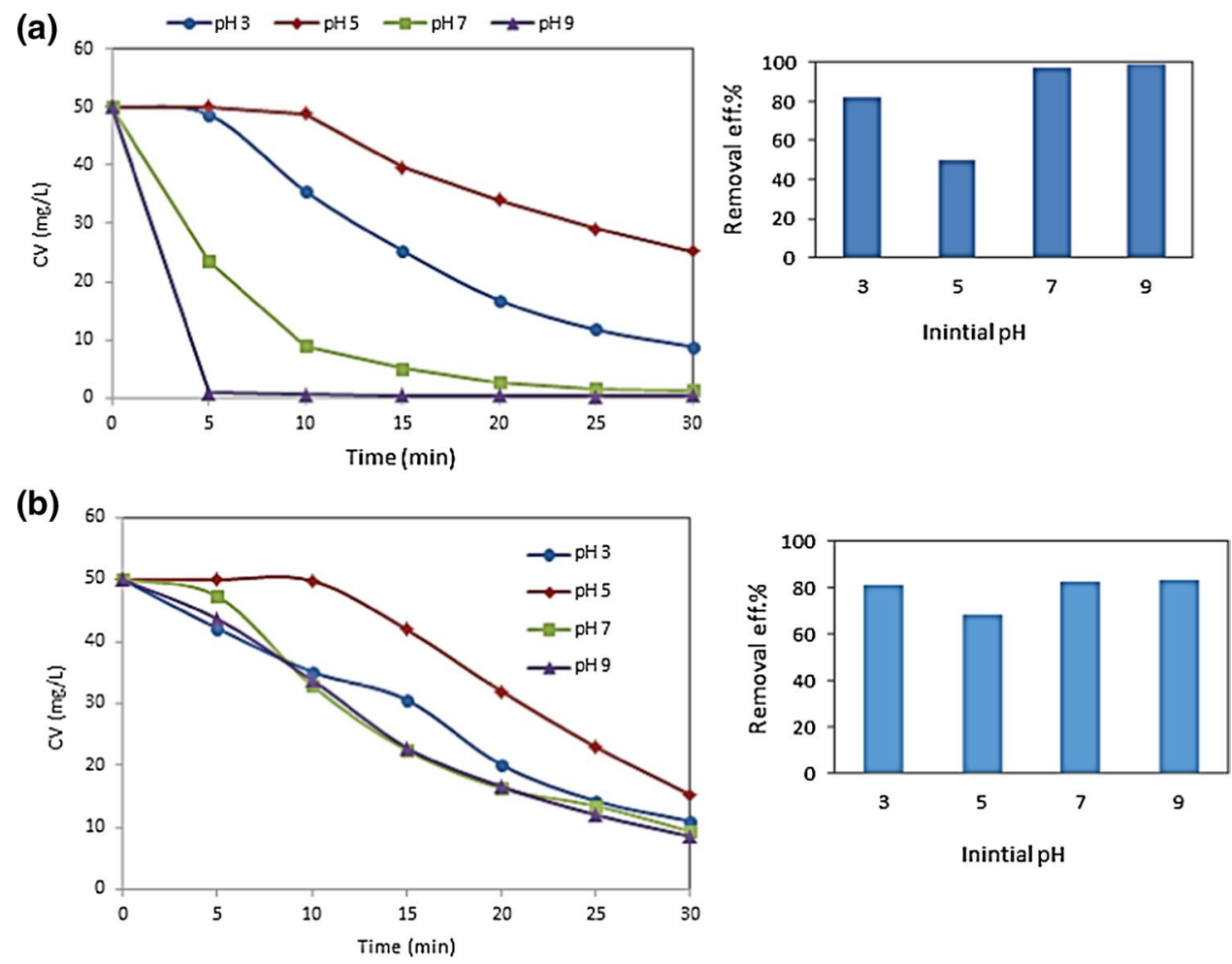


\section{Effect of initial CV concentration}

The effect of initial CV concentration in PO and EPOP processes is shown in Fig. 4. The results demonstrate that the $\mathrm{PO}$ is more effective on $\mathrm{CV}$ removal rather than the EPOP process. Figure $4 \mathrm{a}$ illustrates the ability of the PO process on a different level of $\mathrm{CV}$ concentrations. According to this figure, at the end of the considered time of $30 \mathrm{~min}$, all concentrations $(25-200 \mathrm{mg} / \mathrm{L})$ were decolorized approximately. However, the EPOP process was not able to degrade CV under the same condition. In comparison, the removal efficiency percentage was determined for EPOP process about 61 to $90 \%$, where the overall decolorization efficiency for PO was more than $98 \%$.

Based on Fig. 4b, it is seen that the removal rate of CV is not limited by dye concentrations, owing to the same oxidation pattern of all concentrations ( 25 to $200 \mathrm{mg} / \mathrm{L}$ ).
Also, the removal pattern for each process is a different one from another. These results revealed that the amounts of available $\mathrm{H}_{2} \mathrm{O}_{2}$ and consequently $\mathrm{OH}_{2}{ }^{-}$are limiting factors in this process. As a result, it observed that the $\mathrm{PO}$ is able to decolorize any interring concentration and there limiting factor can be restricted to mixing power and mass transfer of CV.

As shown in Fig. 4c, with an increase in CV concentration, an exponential and a linear decrease in the decolorization rate and the apparent rate constant $\left(k_{\mathrm{app}}, \mathrm{min}^{-1}\right)$ for $\mathrm{PO}$ and EPOP were observed, respectively. The $k_{\text {app }}$ of the $\mathrm{CV}$ decolorization of EPOP at dye concentrations 25, 50, 100, and $200 \mathrm{mg} / \mathrm{L}$ was $7.32 \times 10^{-2}, 6.10 \times 10^{-2}, 2.69 \times 10^{-2}$, and $2.87 \times 10^{2} \mathrm{~min}^{-1}$, respectively. Also, the $k_{\text {app }}$ for PO process was determined about $6.06 \times 10^{-1}, 1.68 \times 10^{-1}, 1.27 \times 10^{-1}$, and $1.09 \times 10^{-1} \mathrm{~min}^{-1}$. It is obvious that the classical PO is more effective on $\mathrm{CV}$ oxidation.
Fig. 4 Effect of initial CV concentrations on peroxone $\mathbf{a}$ and e-peroxone $/ \mathrm{H}_{2} \mathrm{O}_{2}$ efficiency band apparent decolorization rate $\mathbf{c}$ [condition: reactor volume $500 \mathrm{cc}$ and $70 \mathrm{rpm}$, applied current $0.1 \mathrm{~A}, \mathrm{NaCl} 100 \mathrm{mg} / \mathrm{L}$, $\mathrm{pH}$ 9, ozone $2 \mathrm{mg} / \mathrm{L}$. min and $\left.\mathrm{H}_{2} \mathrm{O}_{2} 15 \mathrm{mmol} / \mathrm{L}\right]$
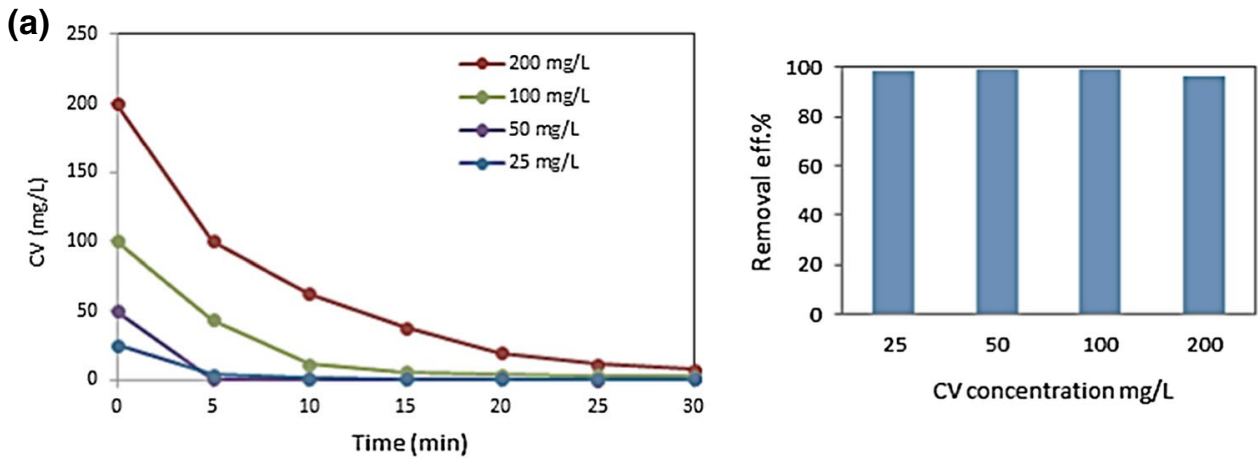

(b)
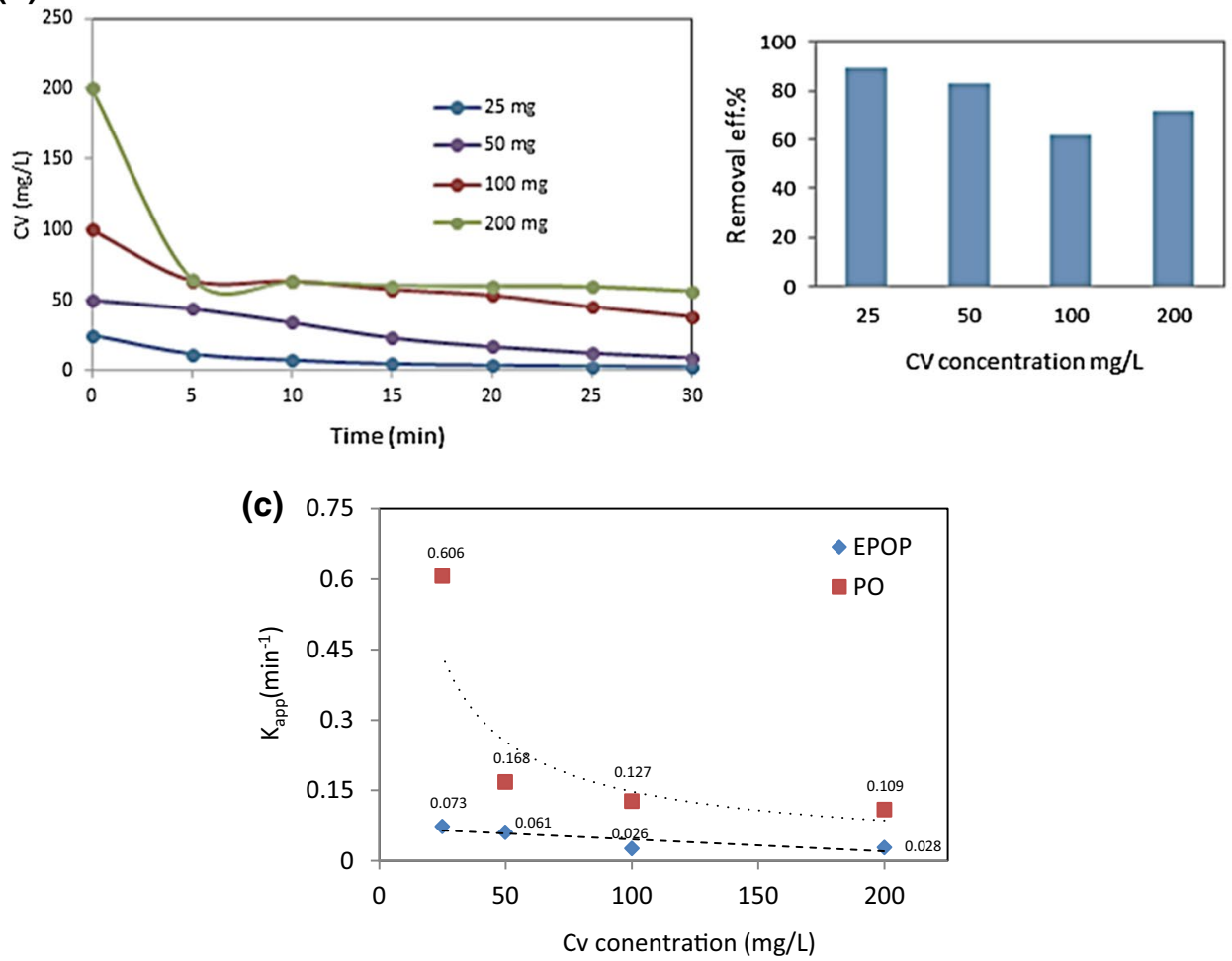


\section{Effect of scavengers}

To investigate the effects of free radical scavenging agents, common organic/inorganic scavengers such as methanol, EDTA, acetate, and sodium bicarbonate were considered. Figure 5 presents the behavior of PO and EPOP processes in the presence of scavengers in comparison with blank. The results indicate that the added organic matter consumes the free radicals and thus lowers the decolorization rates. This negative effect was significantly affected by EPOP processes. The removal efficiency of EPOP process was lost about $38 \%$ to $54 \%$, in the presence of scavengers. Among the tested materials, methanol and EDTA showed more affinity to
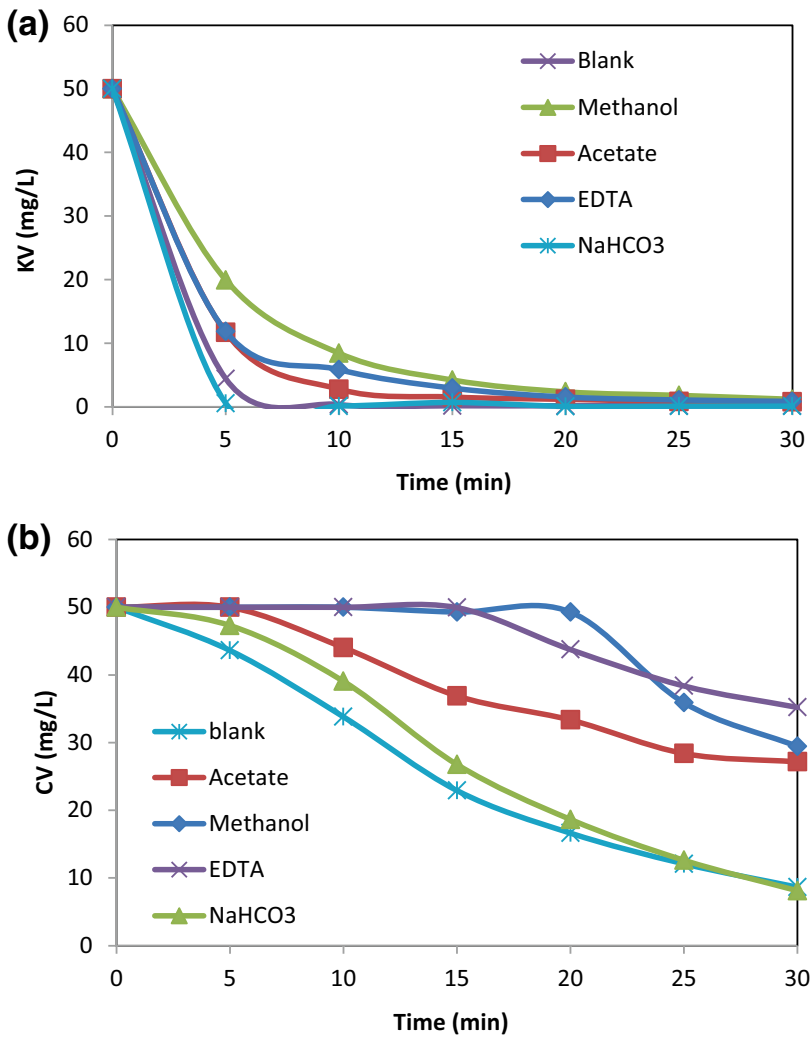

Fig. 5 Effects of free radical scavengers on peroxone a and e-peroxone $/ \mathrm{H}_{2} \mathrm{O}_{2}$ b efficiency condition: reactor volume $500 \mathrm{cc}$ and $70 \mathrm{rpm}$, applied current $0.1 \mathrm{~A}, \mathrm{NaCl} 100 \mathrm{mg} / \mathrm{L}, \mathrm{pH}$ 9, ozone $2 \mathrm{mg} / \mathrm{L}$. min and $\mathrm{H}_{2} \mathrm{O}_{2} 15 \mathrm{mmol} / \mathrm{L}$ consume free radicals. In the PO process, despite observing the negative effect of organic matter, they had a relatively short effect on primary time the PO operation. The scavenging effects of organic matter were in the same way for both processes. Moreover, sodium bicarbonate created the lowest scavenging manner compared to the other agents. The decline in oxidation in the presence of scavengers is related to their higher affinity to react with free radicals. The reaction rate of generation of hydroxyl radical (Eq. 6) is about $1.1 \times 10^{5} \mathrm{M}^{-1} \mathrm{~s}^{-1}$. In comparison with the reaction rate of hydroxyl radical with organic matter $\left(n \times 10^{7}-\mathrm{n} \times 10^{9} \mathrm{M}^{-1}\right.$ $\mathrm{s}^{-1}$ ), it can be concluded that a part of generated radicals is consumed by scavengers. Table 1 shows the reaction constant rate of hydroxyl radical with considered scavengers in the present study. Accordingly, the all considered matters could be nominated as scavengers in the presence of radicalbased processes.

\section{Degradation conformity test}

FTIR In order to understand about CV degradation via different oxidation processes, FTIR analysis was considered. Figure 6 illustrates the results of this test. Comparing the FTIR spectrum of degraded dye with control or untreated solution clearly reveals that the $\mathrm{CV}$ was significantly undergrounded by ozone and other oxidative processes. Statistically significant differences between the FTIR spectra of treated solutions and control imply the occurrence of degradation. According to the FTIR plots, noticeable variations are seen in both fingerprint and functional group regions of 3500 to $500 \mathrm{~cm}^{-1}$ of the oxidized samples in comparison with control. These noticeable variations occurred for all oxidation processes (Ameen et al. 2013). The sharpest peaks for the untreated sample were mono-substituted and para-disubstituted benzene rings, which support the peak at $1583 \mathrm{~cm}^{-1}$. This peak is indexed to the $\mathrm{C}=\mathrm{C}$ stretching of the benzene ring. Also, peaks at $1164 \mathrm{~cm}^{-1}$ and 2920 are indexed to the $\mathrm{C}-\mathrm{N}$ stretching vibrations and $\mathrm{C}-\mathrm{H}$ stretching of the asymmetric $\mathrm{CH}_{3}$ group, respectively. The peak for the $\mathrm{C}-\mathrm{N}$ stretch of aromatic tertiary amine appeared at $1360 \mathrm{~cm}^{-1}$. Moreover, the absence of $\mathrm{N}=\mathrm{N}$ stretching vibrations peak at $1360 \mathrm{~cm}^{-1}$ can be linked to breaking the azo bond. After oxidation of $\mathrm{CV}$, the region between 937
Table 1 Reaction constant rate of hydroxyl radical with some organic and inorganic matters

\begin{tabular}{llll}
\hline Reactant & $\mathrm{k}\left(\mathrm{M}^{-1} \mathrm{~s}^{-1)}\right.$ & Equation & References \\
\hline Organic matter & $\mathrm{N}^{*} \times 10^{7}-\mathrm{n} \times 10^{9}$ & $\bullet \mathrm{OH}+$ Organic $\rightarrow{ }^{\bullet}$ Organic $+\mathrm{H}_{2} \mathrm{O}$ & - \\
Acetate & $1.6 \times 10^{7}$ & $\bullet \mathrm{OH}+\mathrm{CH}_{3} \mathrm{COO}^{-} \rightarrow \mathrm{CH}_{3} \mathrm{COO}{ }^{\bullet}+\mathrm{H}_{2} \mathrm{O}$ & (Armstrong 1969) \\
Methanol & $5.1-6.3 \times 10^{8}$ & $\bullet \mathrm{OH}+\mathrm{HOCH}_{3} \rightarrow \mathrm{H}_{2} \mathrm{O}+{ }^{\bullet} \mathrm{OCH}_{3}$ & (Campbell et al. 1976) \\
EDTA & $4-60 \times 10^{8}$ & $\bullet \mathrm{OH}+\mathrm{EDTA}^{\circ}{ }^{\bullet} \mathrm{EDTA}+\mathrm{H}_{2} \mathrm{O}$ & (Höbel and von Sonntag 1998) \\
Bicarbonate & $8.5 \times 10^{6}$ & $\bullet \mathrm{OH}+\mathrm{HCO}_{3}{ }^{-} \rightarrow \mathrm{H}_{2} \mathrm{O}+{ }^{\bullet} \mathrm{CO}_{3}{ }^{2-}$ & (Buxton and Elliot 1986) \\
\hline
\end{tabular}

$* n=$ a number 

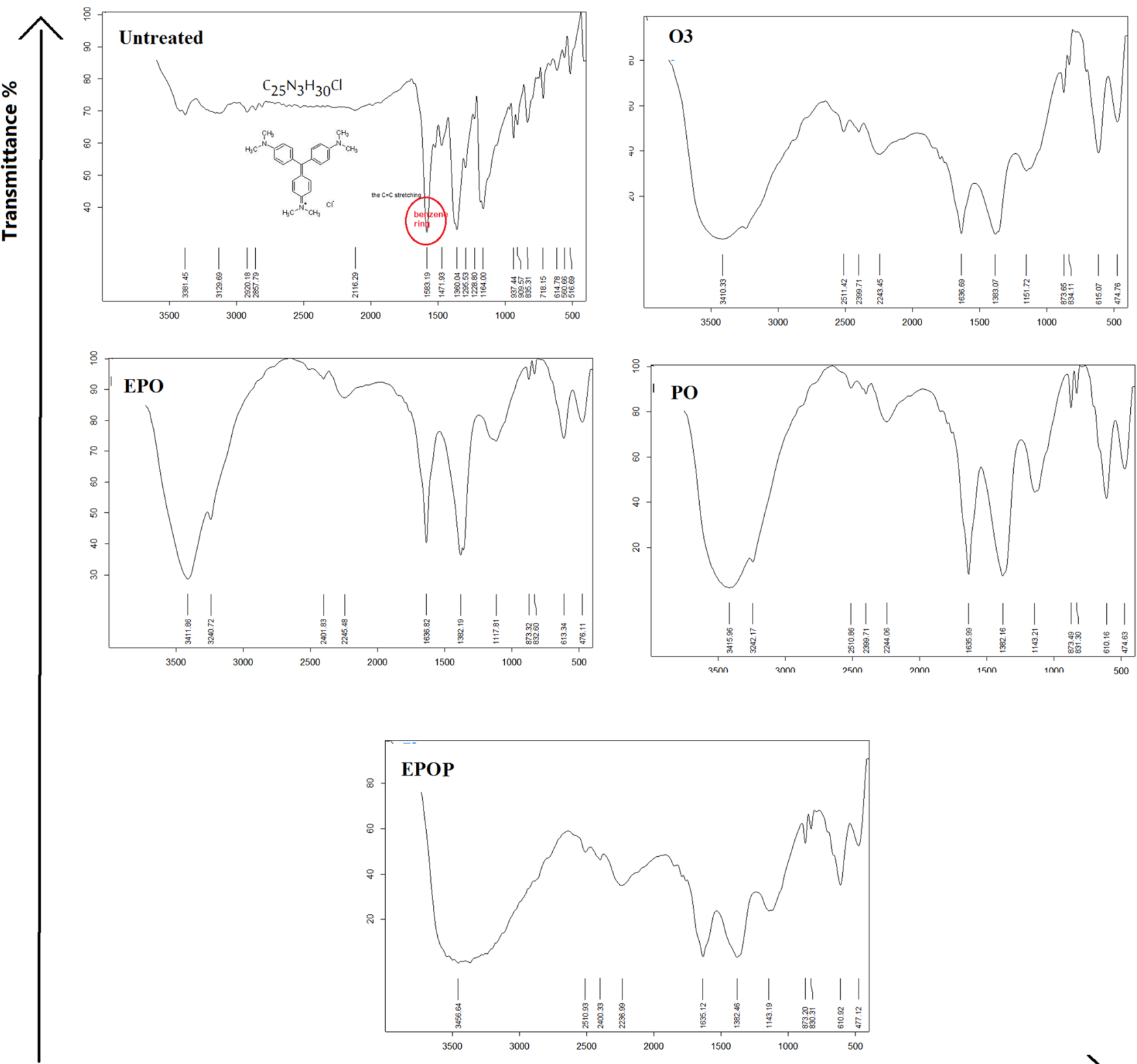

Wavenumber $\mathrm{cm}-1$

Fig. 6 FTIR analysis of treated wastewater with different oxidation processes

and $516 \mathrm{~cm}^{-1}$ disappeared, probably because of the decomposition of aromatic rings.

The level of nitrate To better understand the oxidative degree, the inorganic intermediates like nitrogen compounds (e.g., nitrate and ammonia) can be determined. According to Fan et al. (2009), when the CV is degraded by Fenton and Fenton-like processes, many organic and inorganic intermediates can appear (Fan et al. 2009). These researchers reported degradation intermediates and mineralization pathways of CV. When the CV undergoes an oxidative process, some organic intermediates such as aniline, acetic acid, 4-aminophenol, pararosaniline, aminobenzene, and other aromatic compounds may possibly emerge. Furthermore, at the end of the oxidation process, $\mathrm{CO}_{2}, \mathrm{~N}_{2}, \mathrm{SO}_{4}{ }^{2-}, \mathrm{NO}_{3}{ }^{-}$, and $\mathrm{H}_{2} \mathrm{O}$ were produced through the mineralization process. The presence of this species implies high degradation of target organic compound. Therefore, at this step, the nitrate content was determined at the end of the experiment. The results of this test (Fig. 7) show the occurrence of mineralization. The nitrate concentrations were determined from 0.5 to up then $1 \mathrm{mg} / \mathrm{L}$. In the case of PO, the fewer amount of nitrate possibly is not related to its low degradation degree. This result can be attributed to different degradation path- 


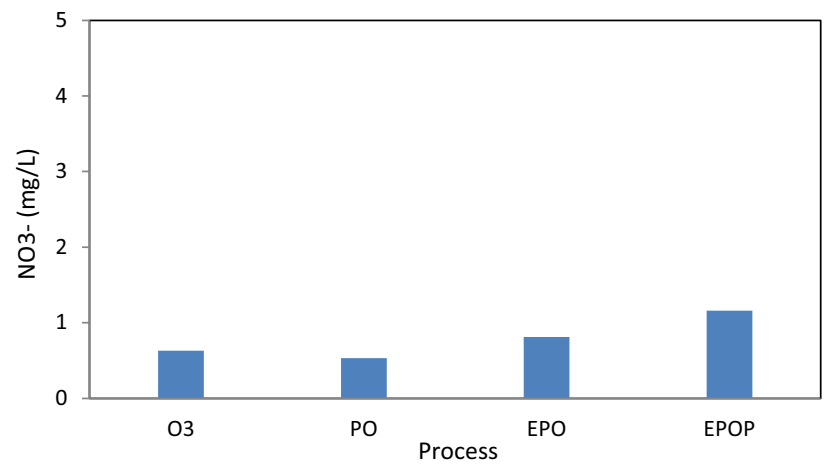

Fig. 7 Nitrate generation levels during ozoation, peroxone, e-proxone, and e-proxone $/ \mathrm{H}_{2} \mathrm{O}_{2}$

ways. In addition, it has been reported that the ozonation of some compounds with aromatic structures increases their toxicity (Shang and Yu 2002).

Toxicity test Triphenylmethane dyes like CV are remarkably used for a wide range of industrial and medical applications. Also, because of their good antimicrobial characteristics and photocytotoxicity properties, they are considered intensively by photodynamic therapy researchers (Fan et al. 2009). In addition, it has been reported that the ozonation of some compounds with aromatic structures increases in toxicity (Shang and Yu 2002). Therefore, CV can be impacted by chemical oxidation and its antimicrobial characteristics are degraded. For better understanding, this variation, the toxicity test was carried out. As presented in Fig. 8, antimicrobial power of $\mathrm{CV}$ changes by the formation of Escherichia coli colonies on the EMB medium. Accordingly, it is clear that significant colony growth exists for all treated samples compared to the untreated sample. However, the fine colony of $E$. coli appeared in the control plate that can occur due to the relatively low effect of $\mathrm{CV}$ toxicity on $E$. coli. Nevertheless, the important key is the appearance of colonies in the samples exposed to degraded ones. The byproducts of a degraded CV such as aniline, benzylamine, and 4-aminobenzoic acid are more toxic than a CV, suggesting a decrease in the overall toxic storage. This result can assure the possible discharging of treated effluent.

\section{Conclusion}

In this study, the effect of ozonation, electrolysis, electrolysis $/ \mathrm{H}_{2} \mathrm{O}_{2}$, peroxone, electro-peroxene, and electro-peroxene/ $\mathrm{H}_{2} \mathrm{O}_{2}$ was examined for decolorization of $\mathrm{CV}$ from aqueous solutions. Results showed that peroxone and electroerosion/ $\mathrm{H}_{2} \mathrm{O}_{2}$ were more effective than other studied compounds. To investigate the effects of radical scavengers, the methanol and EDTA had more affinity to scavenge the free hydroxyl radical. The qualitative and quantitative analyses of intermediates compounds by FTIR and nitrate content showed the occurrence of $\mathrm{CV}$ degradation. Finally, according to
Fig. 8 E. coli growth colonies in the presence of treated wastewater with ozoation, peroxone, e-proxone, and e-proxone $/ \mathrm{H}_{2} \mathrm{O}_{2}$

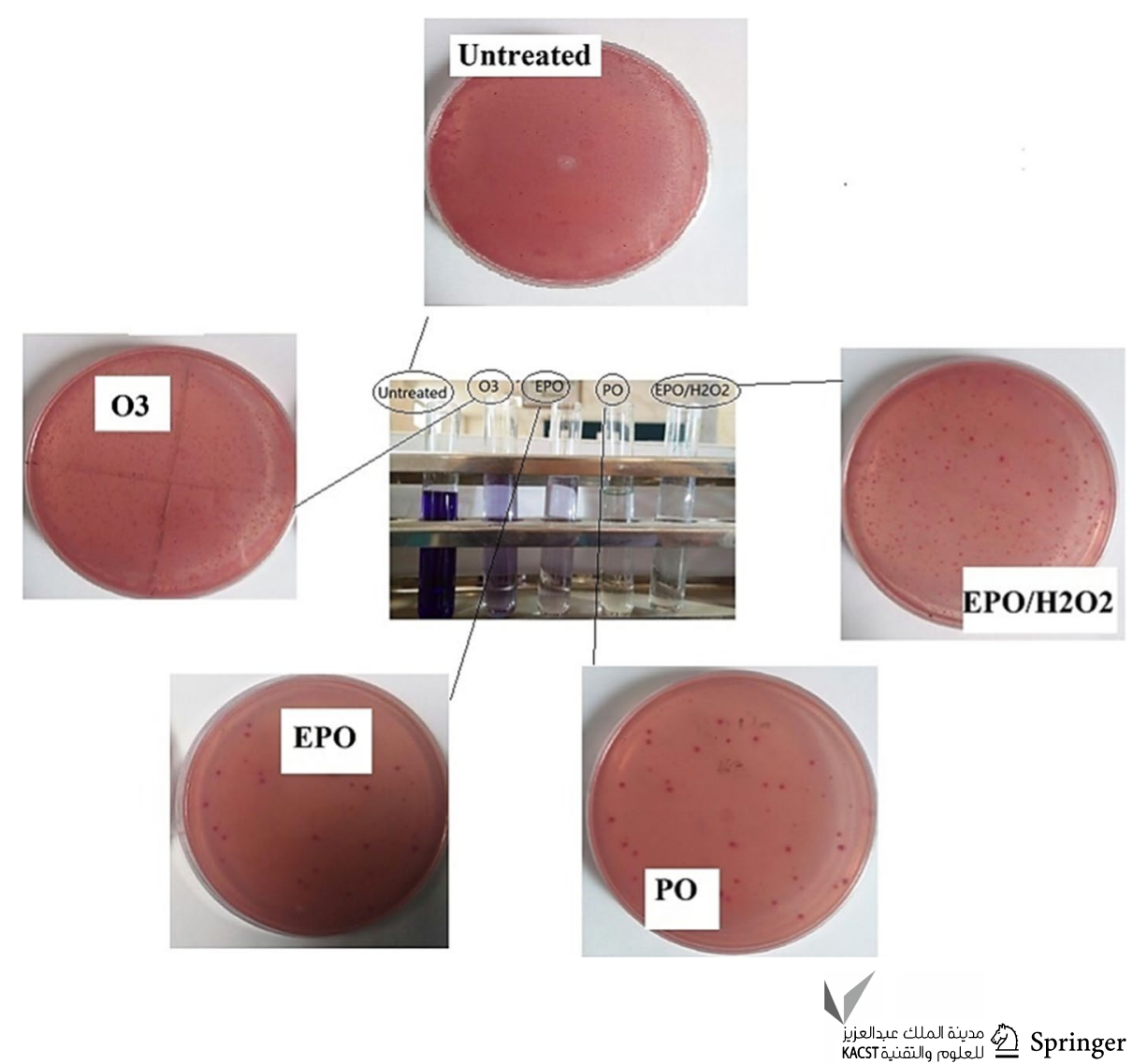


toxicity test and growth of Escherichia coli colonies, it can be concluded that the $\mathrm{CV}$ by-product can be discharged to the environment.

Acknowledgement The authors gratefully acknowledge the Research Council of Kermanshah University of Medical Sciences (Grant Number: 97061) for the financial support. The authors declare that there is no conflict of interest.

Open Access This article is licensed under a Creative Commons Attribution 4.0 International License, which permits use, sharing, adaptation, distribution and reproduction in any medium or format, as long as you give appropriate credit to the original author(s) and the source, provide a link to the Creative Commons licence, and indicate if changes were made. The images or other third party material in this article are included in the article's Creative Commons licence, unless indicated otherwise in a credit line to the material. If material is not included in the article's Creative Commons licence and your intended use is not permitted by statutory regulation or exceeds the permitted use, you will need to obtain permission directly from the copyright holder. To view a copy of this licence, visit http://creativecommons.org/licenses/by/4.0/.

\section{References}

Acar E, Ozbelge T (2006) Oxidation of Acid Red-151 aqueous solutions by the peroxone process and its kinetic evaluation. Ozone Sci Eng 28(3): 155-164

Adhoum N, Monser L (2004) Decolourization and removal of phenolic compounds from olive mill wastewater by electrocoagulation. Chem Eng Process 43(10):1281-1287

Al-Qodah Z, Al-Shannag M (2019) On the Performance of Free Radicals Combined Electrocoagulation Treatment Processes. Sep Purif Rev 48(2):143-158

Al-Qodah Z, Al-Shannag M, Bani-Melhem K, Assirey E, Yahya MA, Al-Shawabkeh A (2018) Free radical-assisted electrocoagulation processes for wastewater treatment. Environ Chem Lett 16(3):695-714

Ameen S, Akhtar MS, Nazim M, Shin H-S (2013) Rapid photocatalytic degradation of crystal violet dye over $\mathrm{ZnO}$ flower nanomaterials. Mater Lett 96:228-232

Armstrong W (1969) Relative rate constants for reactions of hydroxyl radicals from the reaction of $\mathrm{Fe}(\mathrm{II})$ or $\mathrm{Ti}(\mathrm{III})$ with $\mathrm{H} 2 \mathrm{O} 2$. Can $\mathrm{J}$ Chem 47(20):3737-3744

Bakheet B, Yuan S, Li Z, Wang H, Zuo J, Komarneni S, Wang Y (2013) Electro-peroxone treatment of Orange II dye wastewater. Water Res 47(16):6234-6243

Buxton GV, Elliot AJ (1986) Rate constant for reaction of hydroxyl radicals with bicarbonate ions. Int J Radiat Appl Instrum. Part C. Radiat Phys Chem 27(3):241-243

Campbell I, McLaughlin D, Handy B (1976) Rate constants for reactions of hydroxyl radicals with alcohol vapours at $292 \mathrm{~K}$. Chem Phys Lett 38(2):362-364

Chen G (2004) Electrochemical technologies in wastewater treatment. Sep Purif Technol 38(1):11-41

Chou S, Huang Y-H, Lee S-N, Huang G-H, Huang C (1999) Treatment of high strength hexamine-containing wastewater by electroFenton method. Water Res 33(3):751-759

Comninellis C, Kapalka A, Malato S, Parsons SA, Poulios I, Mantzavinos D (2008) Advanced oxidation processes for water treatment: advances and trends for R\&D. J Chem Technol Biotechnol: Int Res Process, Environ Clean Technol 83(6):769-776
De Witte B, Dewulf J, Demeestere K, Van Langenhove H (2009) Ozonation and advanced oxidation by the peroxone process of ciprofloxacin in water. J Hazard Mater 161(2-3):701-708

Fan H-J, Huang S-T, Chung W-H, Jan J-L, Lin W-Y, Chen C-C (2009) Degradation pathways of crystal violet by Fenton and Fenton-like systems: condition optimization and intermediate separation and identification. J Hazard Mater 171(1-3):1032-1044

Feng Y, Li XY (2003) Electro-catalytic oxidation of phenol on several metal-oxide electrodes in aqueous solution. Water Res 37(10):2399-2407

Glaze WH, Kang JW, Chapin DH (1987) The chemistry of water treatment processes involving ozone hydrogen peroxide and ultraviolet radiation. Ozone Sci Eng 9(4):335-352

Harifi-Mood AR, Hadavand-Mirzaie F (2015) Adsorption of basic violet 16 from aqueous solutions by waste sugar beet pulp: kinetic, thermodynamic, and equilibrium isotherm studies. Chem Speciat Bioavailab 27(1):8-14

Höbel B, von Sonntag C (1998) OH-radical induced degradation of ethylenediaminetetraacetic acid (EDTA) in aqueous solution: a pulse radiolysis study. J Chem Soc Perkin Trans 2(3):509-514

Hoigné J, Bader H, Haag W, Staehelin J (1985) Rate constants of reactions of ozone with organic and inorganic compounds in waterIII. Inorganic compounds and radicals. Water Res 19(8):993-1004

Lee J-W, Choi S-P, Thiruvenkatachari R, Shim W-G, Moon H (2006) Evaluation of the performance of adsorption and coagulation processes for the maximum removal of reactive dyes. Dyes Pigm 69(3):196-203

Li X-Y, Cui Y-H, Feng Y-J, Xie Z-M, Gu J-D (2005) Reaction pathways and mechanisms of the electrochemical degradation of phenol on different electrodes. Water Res 39(10):1972-1981

Liu W, Chao Y, Yang X, Bao H, Qian S (2004) Biodecolorization of azo, anthraquinonic and triphenylmethane dyes by white-rot fungi and a laccase-secreting engineered strain. J Ind Microbiol Biotechnol 31(3):127-132

Parshetti G, Parshetti S, Telke A, Kalyani D, Doong R, Govindwar S (2011) Biodegradation of crystal violet by Agrobacterium radiobacter. J Environ Sci (China) 23(8):1384-1393

Rezaee A, Pourtagi G, Hossini H, Loloi M (2016) Microbial cellulose as a support for photocatalytic oxidation of toluene using $\mathrm{TiO} 2$ nanoparticles. J Appl Polym Sci 133(8):43051

Rodgers JD, Bunce NJ (2001) Electrochemical treatment of 2, 4, 6-trinitrotoluene and related compounds. Environ Sci Technol 35(2):406-410

Shang N-C, Yu Y-H (2002) Toxicity and color formation during ozonation of mono-substituted aromatic compounds. Environ Technol 23(1):43-52

Sihem A, Kamel D, Halima C, Tahar S, Abdlkader B, Azzedine RD (2008) Elimination of a cationic dye (Crystal violet) in aqueous medium by TiO2/UV oxidation process. Asian J Chem 20(7):5581

Wijannarong S, Aroonsrimorakot S, Thavipoke P, Sangjan S (2013) Removal of reactive dyes from textile dyeing industrial effluent by ozonation process. APCBEE procedia 5:279-282

Zhang H, Wu J, Wang Z, Zhang D (2010) Electrochemical oxidation of crystal violet in the presence of hydrogen peroxide. J Chem Technol Biotechnol 85(11):1436-1444

Publisher's Note Springer Nature remains neutral with regard to jurisdictional claims in published maps and institutional affiliations. 